\title{
Radiolytic Synthesis of Vinyl Polymer-Clay Nanocomposite Membranes for Direct Methanol Fuel Cell
}

\author{
Yoon-Seob Kim, Yun Ok Kang, and Seong-Ho Choi \\ Department of Chemistry, Hannam University, Daejeon 305-811, Republic of Korea \\ Correspondence should be addressed to Seong-Ho Choi; shchoi@hnu.kr
}

Received 10 October 2013; Accepted 10 February 2014; Published 26 March 2014

Academic Editor: Tianxi Liu

Copyright (C) 2014 Yoon-Seob Kim et al. This is an open access article distributed under the Creative Commons Attribution License, which permits unrestricted use, distribution, and reproduction in any medium, provided the original work is properly cited.

The three-type vinyl polymer-clay nanocomposite membranes with sulfonate $\left(-\mathrm{SO}_{3} \mathrm{Na}\right)$ are prepared by the solvent casting method after radiation-induced copolymerization for application of the direct methanol fuel cell (DMFC) membrane. The three-type vinyl polymers in polymer-clay nanocomposite membranes are included in poly(styrene-co-sodium styrene sulfonate), poly(St-co-NaSS), poly(2-hydroxyethyl methacrylate-co-NaSS), poly(HEMA-co-NaSS), and poly(acrylic acid-co-NaSS), and poly(AAc-co-NaSS). The proton conductivity $(\mathrm{S} / \mathrm{cm})$, water uptake $(\%)$, and ion-exchange capacity (meq/g) of the poly(St-co-NaSS)-clay nanocomposite membrane are $0.0779,32.4,3.63$, respectively. The $\mathrm{MeOH}$ permeability of the poly(St-co-NaSS)-clay nanocomposite membrane is exhibited as $7.7 \times 10^{-9} \mathrm{mmol} \cdot \mathrm{cm}^{-2} \cdot \mathrm{s}^{-1}$. DMFC performance for poly(St-co-NaSS)-clay nanocomposite membrane is also measured in cell voltage and power density verses current density. As results, the poly(St-co-NaSS)-clay nanocomposite membrane can be used as a DMFC membrane on behalf of the commercial Nafion membrane.

\section{Introduction}

Direct methanol fuel cell (DMFC) $[1,2]$ and polymer electrolyte membranes fuel cell (PEMFC) [3, 4] have recently received much attention due to these power sources presenting a high-energy efficiency and low emission of pollutants. For PEMFC, hydrogen was used as fuel and delivered the power density of $300-500 \mathrm{Wcm}^{-2}$ at $80-90^{\circ} \mathrm{C}$. While there are many problems such as production, storage, and transportation of hydrogen using hydrogen as a fuel, the DMFC has attracted more attention than PEMFC when using liquid methanol as fuel, which is easy to deliver and store. More importantly, methanol fuel can be used at ambient temperature and pressure, which makes the DMFC easy to be applied to portable electronic devices [5]. However, the development of DMFC has faced several serious problems: (i) slow methanol oxidation kinetics [6], (ii) the poisoning of CO intermediate on the Pt surface [7], (iii) the high methanol cross-over through the polymer membrane $[8,9]$, and (iv) the high costs of the Nafion membrane and Pt catalyst $[10,11]$.

Presently, the perfluorosulfonate ionomer membranes, such as Nafion membrane (Dupont), are the primary polymer membranes used on the DMFC. However, the commercial Nafion polymer membranes showed a serious methanol cross-over problem, which $\mathrm{MeOH}$ permeates from the anode to the cathode. The $\mathrm{MeOH}$ permeation not only causes a loss of fuel but also a mixed potential being formed at the cathode leading to a lower electrochemical performance of the DMFC. Thus, for the liquid $\mathrm{MeOH}$ fuel cell, it is imperative that the most important characteristic properties of a solid polymer membrane on the DMFC must have a lower $\mathrm{MeOH}$ permeation of liquid fuel.

In order to overcome $\mathrm{MeOH}$ crossover in DMFC, polymer-inorganic material composite membranes were prepared from many researchers. Yang and Lee [12] synthesized the $\mathrm{PVA} / \mathrm{MMT}$ polymer membrane and determined the $\mathrm{MeOH}$ permeability at $3-4 \times 10^{-6} \mathrm{~cm}^{2} \mathrm{~s}^{-1}$. Lee et al. [13] also prepared the disulfonated poly(arylene ether sulfone)-silica nanocomposites membrane for DMFC and determined the $\mathrm{MeOH}$ permeability as $10^{-6} \sim 10^{-7} \mathrm{~cm}^{2} \mathrm{~s}^{-1}$ value at $30^{\circ} \mathrm{C}$. Sulfonated poly(ether ether ketone) (SPEEK) membrane-clay composite membrane was also prepared by Jaafar et al. [14] and also determined methanol permeability with a $10^{-9} \sim 10^{-10} \mathrm{~cm}^{2} \mathrm{~s}^{-1}$ 
TABLE 1: Preparation condition of three-type vinyl polymer-clay nanocomposites for DMFC membrane ${ }^{\mathrm{a}}$.

\begin{tabular}{lcccccccc}
\hline Sample & St $(\mathrm{g})$ & HEMA $(\mathrm{g})$ & NaSS $(\mathrm{g})$ & AAc $(\mathrm{g})$ & O-MMT $(\mathrm{g})$ & $\mathrm{MeOH}(\mathrm{mL})$ & $\mathrm{H}_{2} \mathrm{O}(\mathrm{mL})$ & $2-\mathrm{Propanol}(\mathrm{mL})$ \\
\hline Number 1 & 18.0 & - & - & 27.0 & 3.50 & 200 & 200 & 40.0 \\
Number 2 & - & 18.0 & - & 27.0 & 3.50 & 200 & 200 & 40.0 \\
Number 3 & - & - & 18.0 & 27.0 & 3.50 & 200 & 200 & 40.0 \\
\hline
\end{tabular}

${ }^{\mathrm{a}}$ Total irradiation dose $=30 \mathrm{kGy}\left(\right.$ dose rate $\left.=6.48 \times 10^{5} / \mathrm{h}\right)$.

value. Karthikeyan et al. [15] also prepared SPEEK-MCM41 composite membranes with $10^{-17} \mathrm{~m}^{2} \mathrm{~s}^{-1} \mathrm{pa}^{-1}$. Nafionmontmorillonite composite membrane with $\mathrm{MeOH}$ permeability of $0.042 \mathrm{~mol} / \mathrm{L}$ at $1 \mathrm{~h}$ for DMFC was also prepared by Jung et al. [16] However, little has been reported for the vinyl polymer-clay nanocomposite membrane with low $\mathrm{MeOH}$ permeability.

In a previous paper [17], the preparation of poly(St-coDVB)-clay nanocomposites with a quaternary alkylammonium salt as a intercalating agent by $\gamma$-irradiation copolymerization was reported. It was found that the $\gamma$-irradiation techniques have many advantages for preparation of vinyl polymer-clay nanocomposites. In particular, they need no radical initiators. During $\gamma$-irradiation, free radicals are generated at low temperature. Therefore, the polymer-clay nanocomposites can be simultaneously prepared using the free radicals during $\gamma$-irradiation. However, this poly(St-coDVB)-clay nanocomposite could not be used for DMFC membrane because there are no proton-exchange groups and brittle mechanical properties.

In this study, we prepared a three-type vinyl polymer-clay nanocomposite membrane with sulfonate group $\left(-\mathrm{SO}_{3} \mathrm{Na}\right)$ as the cation transfer site by solution casting method after radiation-induced copolymerization of vinyl monomers. The prepared polymer-clay nanocomposite membrane was characterized by FT-IR, TEM, ion-exchange capacity, wateruptake, proton conductivity, and $\mathrm{MeOH}$ permeability. Furthermore, in order to know the application of the DMFC membrane, DMFC performance for the poly(St-co-NaSS)clay nanocomposite membrane was performed.

\section{Experimental}

2.1. Materials. Butylimidazole, styrene methyl chloride, styrene, sodium styrene sulfonate, acrylic acid, 2-hydroxyethyl methacrylate, and 5.0\% Nafion solution were obtained from Sigma-Aldrich (Yong-in, Korea). The $\mathrm{Na}^{+}$-montmorillonite $\left(\mathrm{Na}^{+}-\mathrm{MMT}\right)$ was obtained from Southern Clay Products, Inc. (Texas, USA). 80 wt.\% PtRu/Vulcan and 80 wt.\% Pt/Vulcan catalysts for DMFC performance were obtained Premetek Co. (USA). Solutions for the experiments were prepared with water purified in a Milli-Q plus water purification system (Millipore Co., Ltd., USA, the final resistance of water was $\left.18.2 \mathrm{M} \Omega \mathrm{cm}^{-1}\right)$. Other chemicals were of reagent grade.

2.2. Preparation of Substituted Imidazolium Salt. 1-[(4-ethylphenyl)methyl]-3-butyl-imidazolium chloride represented here as $[\mathrm{EPMBIM}]^{+}[\mathrm{Cl}]^{-}$was first prepared by the quaternization reaction of butyl imidazole with styrene methyl chloride at $80^{\circ} \mathrm{C}$ for $24 \mathrm{~h}$ in cyclohexane under refluxing condition. The structure of the prepared imidazolium salt was confirmed by ${ }^{1} \mathrm{H}$ NMR spectra (DMSO- $d_{6}$, chemical shift, $\delta /$ ppm relative to TMS): $9.34(\mathrm{~s}, 1 \mathrm{H}), 7.88(\mathrm{t}, 1 \mathrm{H}$, and $J=$ $1.65 \mathrm{~Hz}), 7.79(\mathrm{t}, 1 \mathrm{H}$, and $J=1.65 \mathrm{~Hz}), 4.24(\mathrm{q}, 2 \mathrm{H}$, and $J=$ $7.26 \mathrm{~Hz}), 3.89$ (s and $3 \mathrm{H})$, and $1.42(\mathrm{t}, 3 \mathrm{H}$, and $J=7.26 \mathrm{~Hz}$ ).

2.3. Preparation of Organic-Montmorillonite Clay (O-MMT). Organo-montmorillonite clay (O-MMT) was prepared by the cationic exchange reaction between the sodium cations of MMT clays and the $[\mathrm{EPMBIM}]^{+}[\mathrm{Cl}]^{-}$, as intercalating agent in an aqueous solution as shown in Figure 1. The cationic exchange capacity (CEC) of this clay is 98 meq $100^{-1} \mathrm{~g}$. The suspension solution containing $\mathrm{Na}^{+}-$ MMT/[EPMBIM $]^{+}[\mathrm{Cl}]^{-}=1 / 1.1$ in CEC was mixed in $250 \mathrm{~mL}$ of distilled water. The suspension solution was stirred at $75^{\circ} \mathrm{C}$ for $24 \mathrm{~h}$ to yield white precipitates. The product was filtered, washed with distilled water, and dried in a vacuum oven at $60^{\circ} \mathrm{C}$ for $12 \mathrm{hrs}$.

\subsection{Preparation of the Vinyl Polymer-Clay Nanocomposite} Membrane by the Solvent Casting Method after RadiationInduced Copolymerization of Vinyl Monomers. Figure 1 shows schematic preparation of the three-type vinyl polymerclay nanocomposite by radiation-induced polymerization and the used vinyl monomer structure. The NaSS was used in order to obtain the sulfonate group $\left(-\mathrm{SO}_{3} \mathrm{Na}\right)$ as the cation-exchange group. The St, HEMA, and AAc were used in order to prepare the membrane. Table 1 exhibits the preparation condition of the three-type vinyl polymer-clay nanocomposites for the DMFC membrane. The suspension solution was bubbled with nitrogen gas to remove oxygen for $30 \mathrm{~min}$ and irradiated from a Co-60 source under atmospheric pressure and ambient temperature. A total irradiation dose of $30 \mathrm{kGy}\left(\right.$ dose rate $\left.=6.48 \times 10^{5} \mathrm{~h}^{-1}\right)$ was used. The final products were filtered and then dried in a vacuum oven at $50^{\circ} \mathrm{C}$ for $6 \mathrm{~h}$.

The vinyl polymer-clay nanocomposite membrane was prepared by drying the polymer-clay nanocomposite DMF solution $(7.0 \mathrm{wt} .-\%)$ in a glass plate at $70^{\circ} \mathrm{C}$ for $24 \mathrm{hrs}$.

2.5. Characterizations. The surface Fourier transform infrared (FT-IR) absorption spectra were obtained with FTIR spectrum IS10 spectrometer (Thermo scientific Co., USA) in the range of $4000-650 \mathrm{~cm}^{-1}$. The surface morphology of the polymer-clay nanocomposites was determined by FE-TEM (JEOL, JEM-2100F, USA) and FE-SEM (S-4800, Hitachi Science System Co., Japan). Thermal gravimetric analysis (TGA) was conducted on a Scinco TGA S-1000 


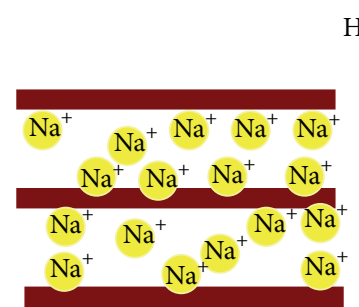

$\mathrm{Na}^{+}$-montmorillonite $\left(\mathrm{Na}^{+}-\mathrm{MMT}\right)$

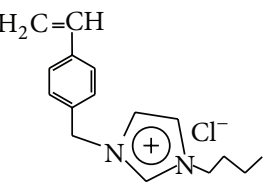

$\mathrm{H}_{2} \mathrm{O}, 75^{\circ} \mathrm{C}, 24 \mathrm{~h}$

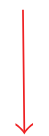

-



Organo-montmorillonite (O-MMT)

$\gamma$-Irradiation

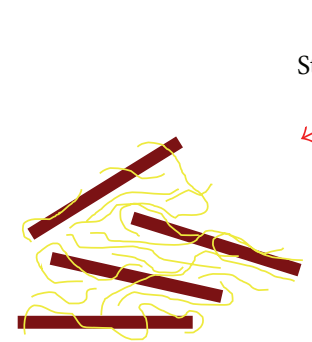

Poly(St-co-NaSS)-OMMT nanocomposite (number 1)

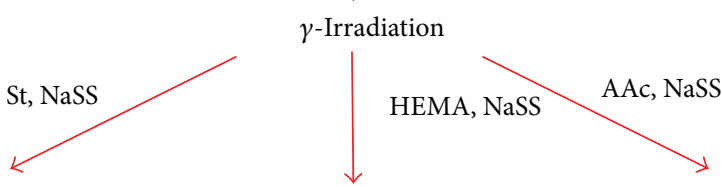

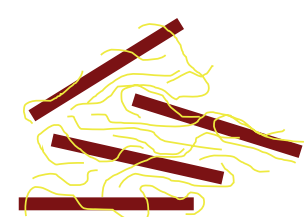

Poly(HEMA-co-NaSS)-O-

MMT nanocomposite

(number 2)



Poly(AAc-co-NaSS)-OMMT nanocomposite (number 3)

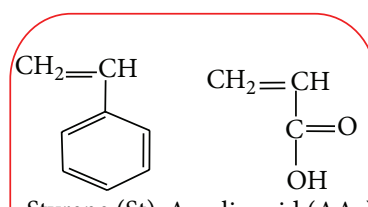

Styrene (St) Acrylic acid (AAc)<smiles>C=C(C)C(=O)OCCO</smiles>

2-Hydroxyethyl methacrylate (HEMA)<smiles>Cc1ccc(S(=O)(=O)O[Na])cc1</smiles>

Sodium styrene sulfonate (NaSS)

FIGURE 1: Schematic preparation of the three-type vinyl polymer-clay nanocomposite by radiation-induced polymerization.

(Seoul, Korea) under $\mathrm{N}_{2}$ flow from $25^{\circ} \mathrm{C}$ to $700^{\circ} \mathrm{C}$ at a heating rate of $20^{\circ} \mathrm{C} \mathrm{min}^{-1}$. The water uptake (\%) was determined as follows:

$$
\text { Water uptake }(\%)=\left[\left(\frac{W_{w}}{W_{g}}\right) \cdot W_{g}^{-1}\right] \times 100,
$$

where $W_{w}$ and $W_{g}$ are the weight of the polymer-clay nanocomposite membrane in the wetting and drying condition, respectively. In order to determine ion-exchange capacity of the polymer-clay nanocomposite membrane, the prepared membrane $(1.0 \mathrm{~cm} \times 1.0 \mathrm{~cm})$ was placed in $0.5 \mathrm{M} \mathrm{HCl} \mathrm{solu-}$ tion for $24 \mathrm{hrs}$ and then the membrane with sulfonic acid $\left(-\mathrm{SO}_{3} \mathrm{H}\right)$ was inserted into $1.0 \mathrm{M} \mathrm{NaCl}$ solution for $24 \mathrm{hrs}$. The solution with $\mathrm{H}^{+}$ions was titrated with $0.01 \mathrm{M} \mathrm{NaOH}$ solution. Here, ion-exchange capacity (meq/g) of the polymerclay nanocomposite membrane was determined by titration method as in the following equation:

$$
\text { Ion-exchange capacity }(\mathrm{meq} / \mathrm{g})=\frac{\left(N_{\mathrm{NaOH}} \times V_{\mathrm{NaOH}}\right)}{W_{g}},
$$

where the $N_{\mathrm{NaOH}}$ and $V_{\mathrm{NaOH}}$ mean the normal concentration and volume for the addition of $\mathrm{NaOH}$ solution, respectively. The proton conductivity $(\mathrm{S} / \mathrm{cm})$ of the polymer-clay nanocomposite membrane was measured by AC impedance (IM-6ex, Zahner, Germany). The proton conductivity of the polymer-clay nanocomposite membrane was calculated as in the following equation:

$$
\sigma=\frac{L}{R \times A}
$$

where $\sigma$ is proton conductivity of the membrane, $L$ and $R$ mean the length between the Pt electrode and the measured value from AC impedance, respectively. $A$ is the area of the polymer-clay nanocomposite membrane.

The fuel cell performance was performed via the poly(AAc-co-NaSS)-clay nanocomposite membrane assembly (MEA) as shown Figure 2. The anode catalyst inks were firstly prepared by mixing $2.0 \mathrm{mg}$ of commercial $80 \mathrm{wt} . \%$ $\mathrm{PtRu} /$ Vulcan catalysts in isopropanol alcohol with $5.0 \%$ Nafion solution. The anode electrode was prepared by coating of the anode catalyst ink onto the carbon paper surface. The cathode catalysts inks were also prepared by homogeneous mixing of $2.0 \mathrm{mg}$ commercial Pt/Vulcan. Afterwards, the single-cell MEA was fabricated by hot pressing the two electrodes with the prepared PEM under a pressure of $100 \mathrm{Kg} \mathrm{cm}^{-2}$ at $135^{\circ} \mathrm{C}$ for $10 \mathrm{~min}$. The singlecell MEA was installed in a fuel-cell test station (PRO200F, Propower Co., Korea). MeOH solution with $1.0 \mathrm{M}$ flowed on rates of $900 \mathrm{~mL} / \mathrm{min}$ and air flowed on the rates of $2.0 \mathrm{~mL} \cdot \mathrm{min}^{-1}$. Measurements of the polarization curves (voltage versus current density) were conducted under various temperatures.

\section{Results and Discussion}

3.1. Characterization of Vinyl Polymer-Clay Nanocomposite Membrane. Figure 3 presents the FT-IR spectra of $\mathrm{Na}^{+}-\mathrm{MMT}$ (a) O-MMT (b), number 1 (c), number 2 (d), and number 3 (e) in Table 1 in the wavenumber 650 to $4000 \mathrm{~cm}^{-1}$. In the pristine $\mathrm{Na}^{+}$-MMT (Figure 3(a)), a clear broad band in the region $3300-3700 \mathrm{~cm}^{-1}$ was observed which corresponds 


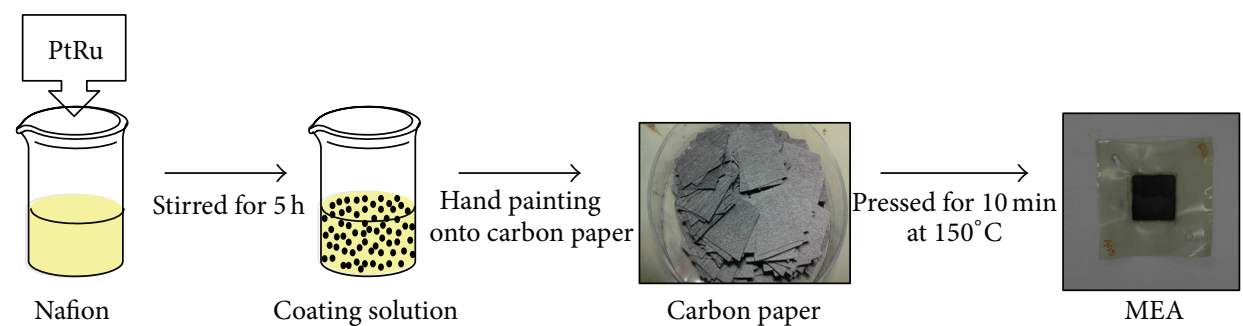

(a)

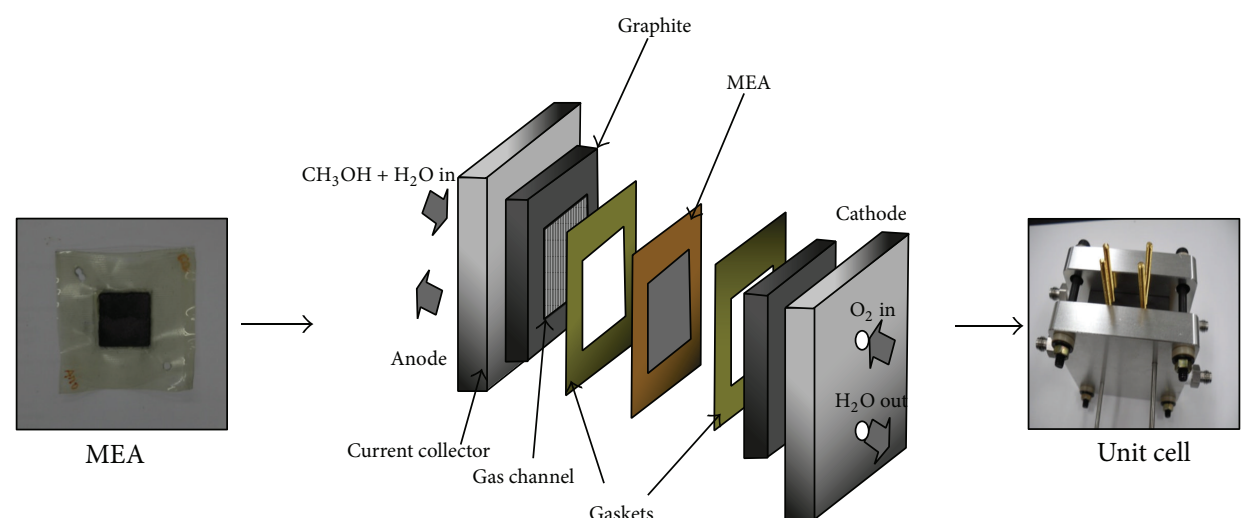

(b)

FIGURE 2: Schematic fabrication of MEA using poly(AAc-co-NaSS)-clay nanocomposite membrane for DMFC.



Figure 3: FR-IR spectra of $\mathrm{Na}^{+}-\mathrm{MMT}$ (a), O-MMT (b), number 1 (c), number 2 (d), and number 3 (e) in Table 1.

to the $-\mathrm{OH}$ stretching vibration. The band has two features at $3620 \mathrm{~cm}^{-1}$ and $3440 \mathrm{~cm}^{-1}$ that can be attributed to the presence of two types of $\mathrm{O}-\mathrm{H}$ groups: isolated $\mathrm{O}-\mathrm{H}$ groups and those involved in hydrogen bonding. The peak observed at $1630 \mathrm{~cm}^{-1}$ is related to the bending vibration mode of hydrated water molecules and weakly bonded water molecules [18]. The strong broad band in the region of $990-1160 \mathrm{~cm}^{-1}$ is likely due to siloxane (Si-O-Si) bond. The nanocomposite prepared by intercalation of imidazolium salt within the interlayer spacing of MMT shows different features in the FT-IR spectra compared to those of pure constituents. In the O-MMT system (Figure 3(b)), it is clear that the intercalation of imidazolium cation has a significant impact upon the structure of MMT. The typical bans of 3620 and $3440 \mathrm{~cm}^{-1}$ in MMT were changed to a new intense band centered at $3620 \mathrm{~cm}^{-1}$ in O-MMT, which corresponds to the increase of isolated hydroxyl groups and the decrease of hydrogen bonding - $\mathrm{OH}$ groups. The peak at $1630 \mathrm{~cm}^{-1}$ corresponding to hydrated water molecules in $\mathrm{O}-\mathrm{MMT}$ is disappeared. This is possibly due to the effect of organophilic transformation of the MMT surfaces caused by $[\mathrm{EPMBIM}]^{+}[\mathrm{Cl}]^{-}$. Moreover, imidazolium cation moieties in the interlayer spacing MMT are determined by the existence of small peaks around 1570 and $1467 \mathrm{~cm}^{-1}$ corresponding to stretching vibration bands of the imidazole ring.

The vinyl group of the O-MMT can be inserted in functional vinyl polymers by radiation-induced copolymerization of the functional vinyl monomers such as sodium styrene sulfonate (NaSS). As results, the O-MMT was well dispersed onto functional vinyl polymers. In the poly(Stco-NaSS)-clay nanocomposite membrane (Figure 3(c)), the characteristic absorption bands were observed at 1490 and $1598 \mathrm{~cm}^{-1}$ related to the $\mathrm{C}=\mathrm{C}$ stretching of the aromatic ring, respectively. The sharp bands at 692 and $754 \mathrm{~cm}^{-1}$ correspond to the $\mathrm{C}-\mathrm{H}$ bending vibration of 1,4-disubstituted benzene. The characteristic $-\mathrm{SO}_{2}{ }^{-}$stretching appeared at $1412 \mathrm{~cm}^{-1}$ 


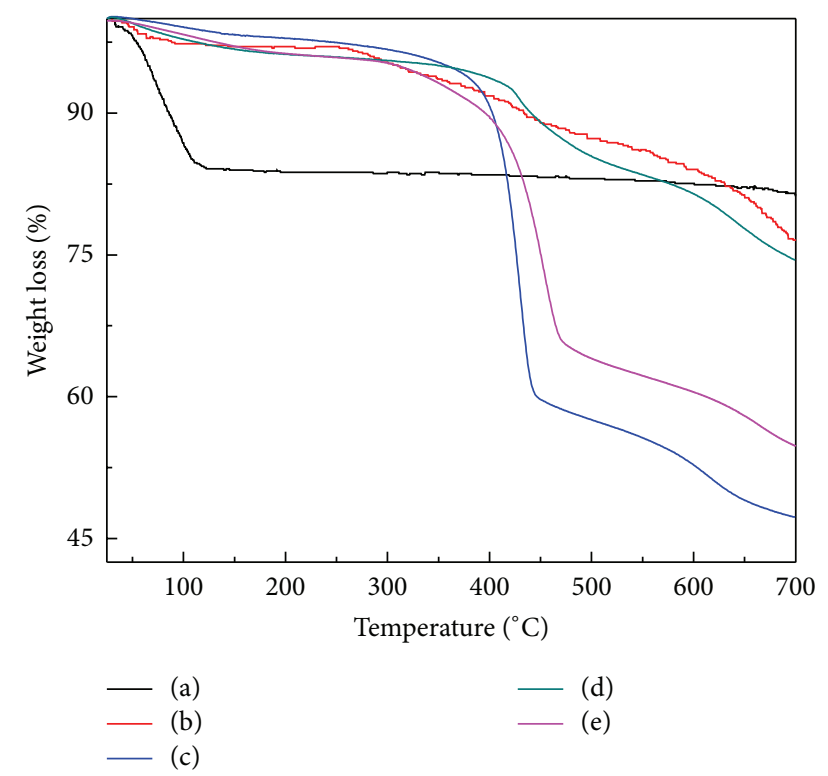

FIgURE 4: TGA curves of $\mathrm{Na}^{+}-\mathrm{MMT}$ (a), O-MMT (b), number 1 (c), number $2(\mathrm{~d})$, and number $3(\mathrm{e})$ in Table 1.

due to the sulfonate site of the poly(NaSS) in nanocomposite membrane. In poly(HEMA-co-NaSS)- and poly(AAc-coNaSS)-clay composite, the characteristic $>\mathrm{C}=\mathrm{O}$ stretching peaks at approximately $1750 \mathrm{~cm}^{-1}$ due to poly(HEMA) and poly(AAc) in the nanocomposite membrane was shown and the characteristic $-\mathrm{SO}_{2}{ }^{-}$stretching appeared at $1412 \mathrm{~cm}^{-1}$ due to the sulfonate site of poly(NaSS) in the nanocomposite membrane. As results, vinyl polymer-clay nanocomposite membranes were successfully synthesized.

Figure 4 shows TGA curves of $\mathrm{Na}^{+}$-MMT (a), O-MMT (b), number 1 (c), number 2 (d), and number 3 (e) in Table 1. In $\mathrm{Na}^{+}$-MMT of Figure 4(a), the first weight loss was observed below $110^{\circ} \mathrm{C}$ due to moisture. In Figure 4(b) (OMMT), a small amount of the first weight loss around $100^{\circ} \mathrm{C}$ due to moisture existed on the imidazolium site of O-MMT, and second weigh loss appeared from $300^{\circ} \mathrm{C}$ to $500^{\circ} \mathrm{C}$ due to [EPMBIM] onto O-MMT. The graft yield (\%) of [EPMBIM] onto O-MMT was calculated about $25 \%$ from TGA curve data. As results, the O-MMT was successfully prepared by the ion-exchange reaction. In the poly(St-co-NaSS)-clay nanocomposite membrane (Figure 4(c)), the small amount of the first weights (\%) at $100^{\circ} \mathrm{C}$ due to moisture onto the sulfonate site of poly(St-co-NaSS) and second weight loss at $450^{\circ} \mathrm{C}$ due to main chain degradation of copolymer matrix was observed. The residue weight (\%) of poly(Stco-NaSS) was to be $75 \%$ because of carbonation of the copolymer matrix. In Figure 4(d), a small amount of first weight loss (\%) was also observed around $\sim 100^{\circ} \mathrm{C}$ due to moisture, and second weighs loss at $400^{\circ} \mathrm{C}$ due to degradation of the copolymer matrix. Similar degradation patterns were also observed in the poly(AAc-co-NaSS)-clay nanocomposite membrane; see Figure 4(e). From these results, the vinyl polymer-clay nanocomposite membranes were successfully prepared by the solvent casting method after radiationinduced copolymerization of feed with the functional vinyl monomers as one-step preparation.

The microstructures of TEM images of $\mathrm{Na}^{+}-\mathrm{MMT}$, O$\mathrm{MMT}$, and vinyl polymer-clay nanocomposites membrane observed by TEM are shown in Figure 5 . The sheets of clay are about 200-300 nm. Individual clay layers are observed looks like line structure onto copolymer. The well-exfoliated clay sheets are indeed observed to be disorderly dispersed in the copolymer matrix (Figure 5, numbers 1, 2, and 3). As a result, the polymer-clay nanocomposite membranes are successfully prepared by radiation-initiated copolymerization of feed with functional vinyl monomers in the presence of O-MMT with the active vinyl group.

Figure 6 exhibits surface SEM and cross-section images of the poly(AAc-co-NaSS)-clay nanocomposite membrane (number 3 in Table 1). In the cross-section image of the membrane, the layer structure appeared due to the clay layer. From these results, we expect to decrease $\mathrm{MeOH}$ permeability since the clay layer protects against $\mathrm{MeOH}$ permeation.

Figure 7 shows ion-exchange capacity (IEC) of vinyl polymer-clay nanocomposite membranes at $25^{\circ} \mathrm{C}$. In order to compare ion-exchange capacity, the commercial Nafion 117 membrane was also measured and denoted in Figure 7. The IEC provides an indication of the ion exchangeable groups presenting in a polymer matrix. The IEC of the vinyl polymer-clay nanocomposite membrane with the sulfonate group was higher than that of the commercial Nafion 117 membrane. We expect the high IEC for poly(AAc-co-NaSS)clay membrane compared to that of the poly(St-co-NaSS)clay membrane and poly(HEMA-co-NaSS)-clay membrane because of the presence of carboxylic acid and the sulfonate group. However, the highest IEC could be obtained by the poly(St-co-NaSS)-clay nanocomposite membrane because of hydrophilic/hydrophobic interface of the polymer structure. As a result, the higher IEC of poly(St-co-NaSS)-clay nanocomposite membrane can be expected to have higher power density in DMFC.

Figure 8 exhibits the proton conductivity of vinyl polymer-clay nanocomposite membranes and commercial Nafion 117 membrane at $25^{\circ} \mathrm{C}$. The proton conductivity of the poly(St-co-NaSS)-clay nanocomposites was higher than that of the commercial Nafion 117 membrane. We expected the higher conductivity to be poly(AAc-co-NaSS)-clay nanocomposite because the charged anions of $-\mathrm{COO}^{-}$and $-\mathrm{S}(=\mathrm{O}) \mathrm{O}^{-}$. However, the lower proton conductivity of the poly(AAc-co$\mathrm{NaSS}$ )-clay nanocomposite membrane was obtained because of hydrogen bonds between carboxylic acid and sulfonic acid in the polymer structure. Many researchers $[19,20]$ reported that the proton can transport through the hydrophilic channels at the hydrophilic/hydrophobic interface of the polymer microstructure.

Figure 9 shows water uptake (\%) of vinyl polymer-clay nanocomposite membranes at $25^{\circ} \mathrm{C}$. Adequate water uptake and successful possession of water molecules are required for effective proton transport across the membrane. However, the water swelling ratio should also be carefully considered because excessive swelling reduces dimensional stability and affects the mechanical properties of the polymer electrolyte 




(a)

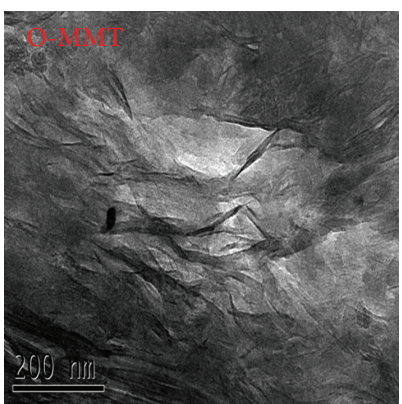

(b)

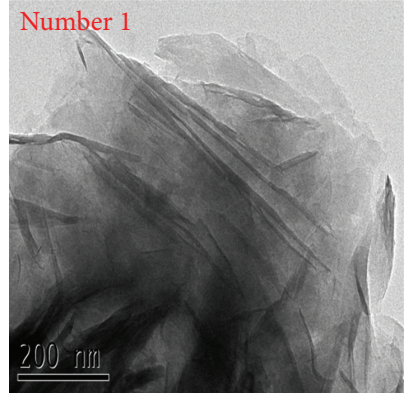

(c)

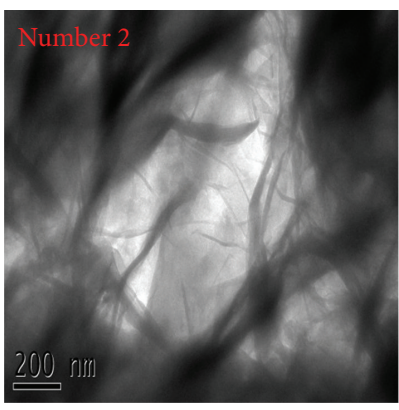

(d)



(e)

FIGURE 5: TEM images of $\mathrm{Na}^{+}$-MMT, O-MMT, and vinyl polymer-clay nanocomposites in Table 1 .

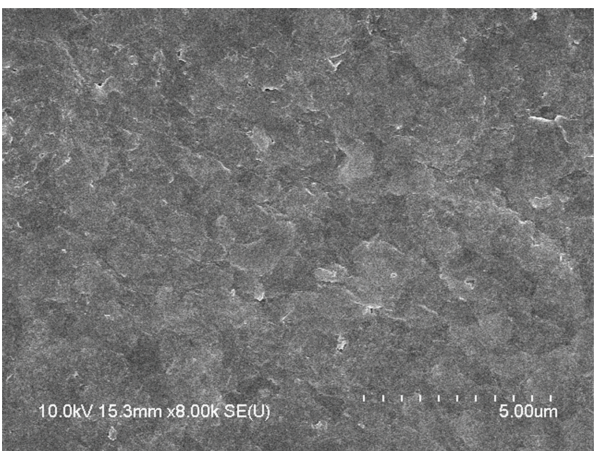

(a)

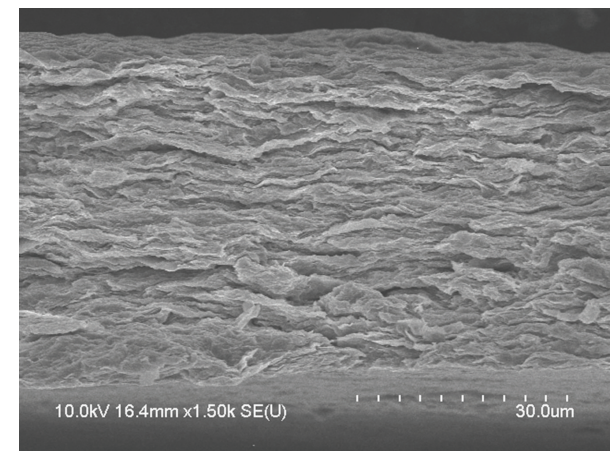

(b)

FIGURE 6: SEM images of the poly(St-co-NaSS)-clay nanocomposite membrane (number 1 in Table 1).

membranes. Despite the high water uptake of the poly(AAcco-NaSS)-clay nanocomposite membrane, the swelling ratio is high, but the poly(St-co-NaSS)-clay nanocomposite membrane possessed the high water uptake and no swelling effects. As a result, the poly(St-co-NaSS)-clay nanocomposite membrane can be successfully used in DMFC membrane.

Table 2 summarized the physical and electrochemical properties of the vinyl polymer-clay nanocomposites membrane prepared by radiation-induced copolymerization of feed with functional vinyl monomers for DMFC. In addition, the physical and electrochemical properties of the commercial Nafion-117 membrane were listed in order to compare properties. The $\mathrm{MeOH}$ permeability for the vinyl polymer-clay nanocomposite membrane was lower than that of the commercial Nafion-117 membrane. From these results, the poly(St-co-NaSS)-clay nanocomposites membrane with hydrophilic/hydrophobic interface in polymer nanostructure can be used in the DMFC membrane.

3.2. DMFC Performance for Poly(AAc-co-NaSS)-Clay Nanocomposite Membrane. In order to know membrane ability, the DMFC performance was performed using MEA with the commercial catalysts. Figure 10 shows DMFC performance of the poly(St-co-NaSS)-clay nanocomposite membrane (a) 
TABLE 2: Physical and electrochemical properties of vinyl polymer-clay nanocomposites membrane for DMFC.

\begin{tabular}{lccccc}
\hline Membrane & $\begin{array}{c}\text { Thickness } \\
(\mu \mathrm{m})^{\mathrm{a}}\end{array}$ & $\begin{array}{c}\text { Proton conductivity } \\
(\mathrm{S} / \mathrm{cm})^{\mathrm{b}}\end{array}$ & $\begin{array}{c}\text { Water uptake } \\
(\%)^{\mathrm{c}}\end{array}$ & $\begin{array}{c}\text { Ion-exchange } \\
\text { capacity }(\mathrm{meq} / \mathrm{g})^{\mathrm{d}}\end{array}$ & $\begin{array}{c}\text { MeOH permeability } \\
\left(\mathrm{mmol} \cdot \mathrm{cm}^{-2} \cdot \mathrm{s}^{-1}\right)^{\mathrm{e}}\end{array}$ \\
\hline Number 1 & 40.0 & 0.0779 & 32.4 & 3.63 & $7.7 \times 10^{-9}$ \\
Number 2 & 50.0 & 0.425 & 22.2 & 2.83 & $\mathrm{ND}$ \\
Number 3 & 50.0 & 0.0524 & 50.4 & 3.04 & $4.4 \times 10^{-6}$ \\
Nafion 117 & 180 & 0.0721 & 5.26 & 0.90 & $2.2 \times 10^{-10}$ \\
\hline
\end{tabular}

${ }^{\mathrm{a}}$ Determined by venier calipers. ${ }^{\mathrm{b}}$ Determined by a AC impedance. ${ }^{\mathrm{c}}$ Determined by dropping test. ${ }^{\mathrm{d}}$ Determined by titration method. ${ }^{\mathrm{e}}$ Determined by GC-FID. ND: not determined.

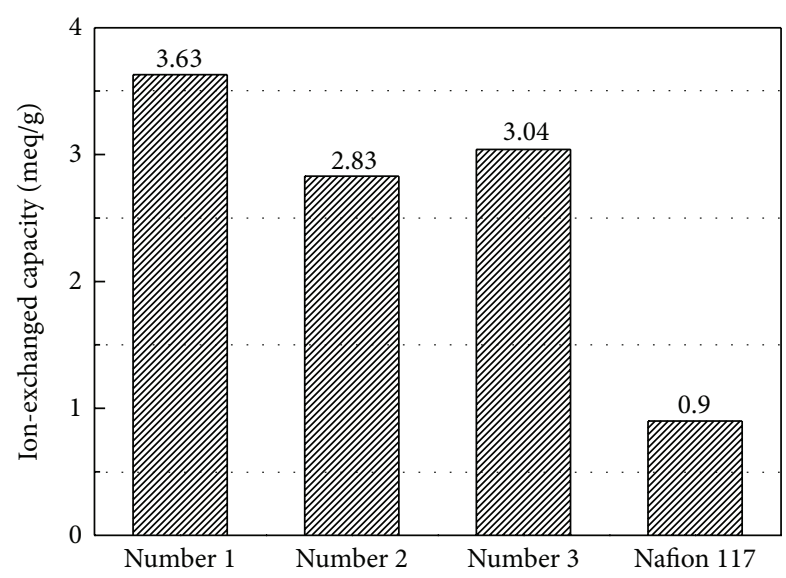

FIGURE 7: Ion-exchange capacity of vinyl polymer-clay nanocomposite membranes at $25^{\circ} \mathrm{C}$.

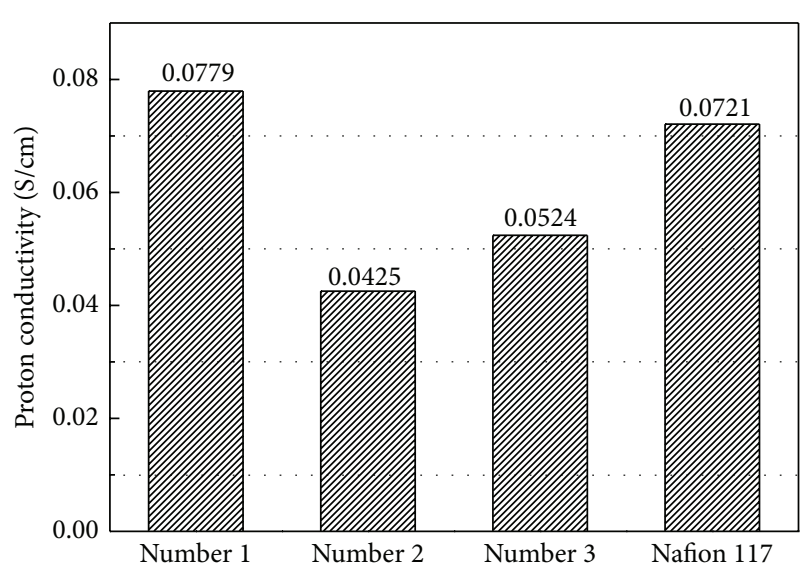

Figure 8: Proton conductivity of vinyl polymer-clay nanocomposite membranes at $25^{\circ} \mathrm{C}$.

and poly(AAc-co-NaSS)-clay nanocomposite membrane (b) at $60^{\circ} \mathrm{C}$. The operating condition of the cathode and anode electrode was fixed in two DMFC performances except for the membrane. As you can see, power density on DMFC performance with the poly(St-co-NaSS)-clay nanocomposite

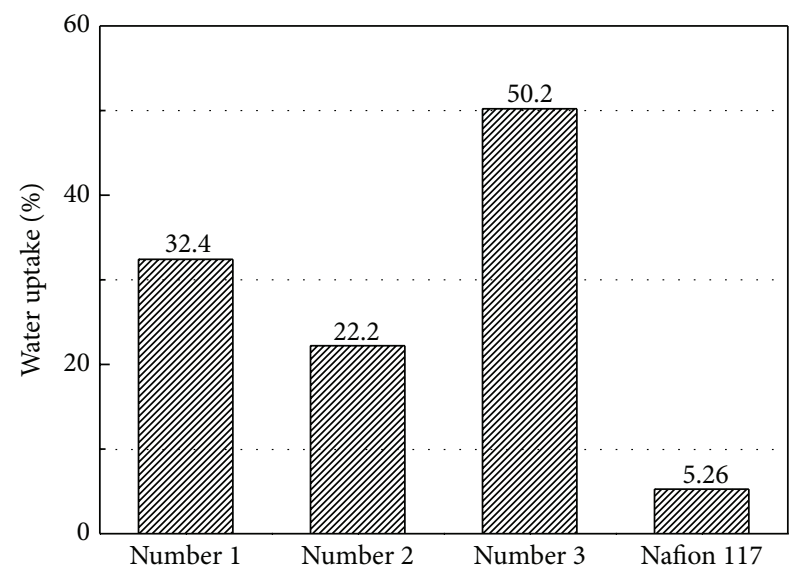

FIGURE 9: Water uptake of vinyl polymer-clay nanocomposite membranes at $25^{\circ} \mathrm{C}$.

membrane being higher than that of the poly(AAc-co-NaSS)clay nanocomposite membrane. From these results, the poly(St-co-NaSS)-clay nanocomposite membrane prepared by radiation-initiated copolymerization of the functional vinyl monomers can be used as a separator in a direct methanol fuel cell.

\section{Conclusion}

Vinyl polymer-clay nanocomposite membranes were synthesized by radiation-induced copolymerization of the functional monomers as a one-step reaction. Polymers were included in poly(St-co-NaSS), poly(HEMA-co-NaSS), and poly(AAc-co-NaSS), respectively. The physical and electrochemical properties of the vinyl polymer-clay nanocomposites membrane were evaluated in order to be applied in the DMFC membrane. Among them, the poly(St-co-NaSS)-clay nanocomposite membrane with hydrophilic/hydrophobic interface in the polymer nanostructure exhibited good physical and chemical properties and high power density. The poly(St-co-NaSS)-clay nanocomposite membrane prepared by radiation-initiated copolymerization of the functional vinyl monomers can be used as a separator in DMFC on behalf of the commercial Nafion-117 membrane. 


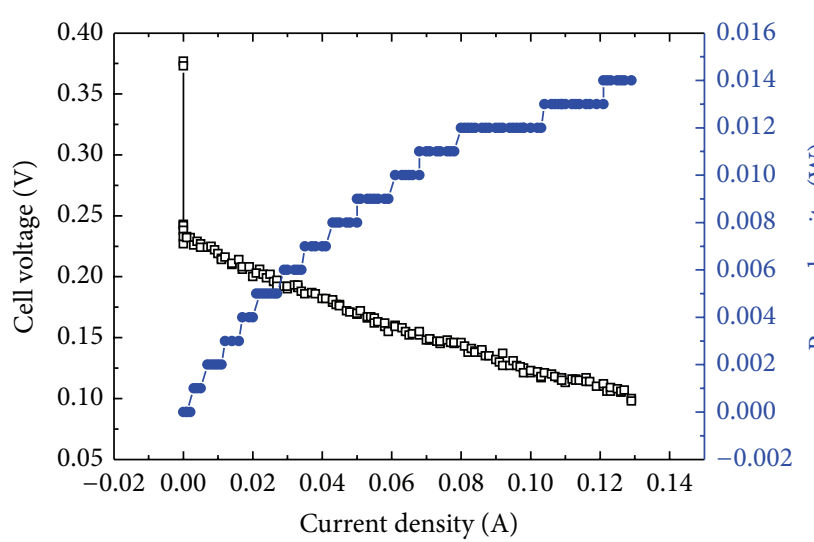

(a)

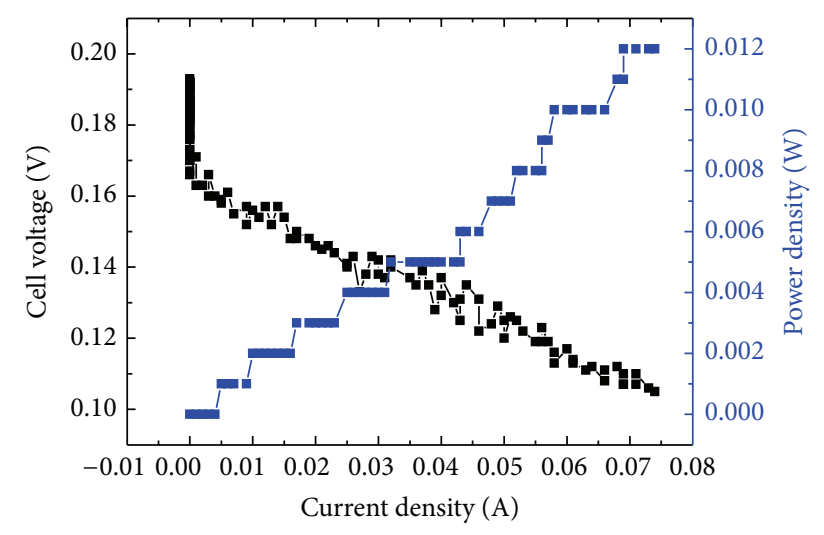

(b)

FIGURE 10: DMFC performance of the poly(St-co-NaSS)-clay nanocomposite membrane (a) and poly(AAc-co-NaSS)-clay nanocomposite membrane (b) at $60^{\circ} \mathrm{C}$.

\section{Disclosure}

The paper has never been published before.

\section{Conflict of Interests}

All authors have read and approved the paper and declare that there is no conflict of interests regarding the publication of this paper.

\section{Acknowledgment}

This work was supported by the National Research Foundation of Korea Grant funded by the Korean Government (2012M2B2A4029347).

\section{References}

[1] T. S. Zhao and C. Xu, "Overview performance and operational conditions," Encyclopedia of Electrochemical Power Sources, vol. 2, pp. 381-389, 2009.

[2] L. Feng, W. Cai, C. Li, J. Zhang, C. Liu, and W. Xing, "Fabrication and performance evaluation for a novel small planar passive direct methanol fuel cell stack," Fuel, vol. 94, pp. 401-408, 2012.
[3] N. Zamel and X. Li, "Effective transport properties for polymer electrolyte membrane fuel cells- with a focus on the gas diffusion layer," Progress in Energy and Combustion Science, vol. 39, no. 1, pp. 111-146, 2013.

[4] B. P. Tripathi and V. K. Shahi, "Organic-inorganic nanocomposite polymer electrolyte membranes for fuel cell applications," Progress in Polymer Science, vol. 36, no. 7, pp. 945-979, 2011.

[5] S. K. Kamarudin, F. Achmad, and W. R. W. Daud, "Overview on the application of direct methanol fuel cell (DMFC) for portable electronic devices," International Journal of Hydrogen Energy, vol. 34, no. 16, pp. 6902-6916, 2009.

[6] Y.-P. Sun, L. Xing, and K. Scott, "Analysis of the kinetics of methanol oxidation in a porous Pt-Ru anode," Journal of Power Sources, vol. 195, no. 1, pp. 1-10, 2010.

[7] P. Hartmann and D. Gerteisen, "Local degradation analysis of a real long-term operated DMFC stack MEA," Journal of Power Sources, vol. 219, pp. 147-154, 2012.

[8] Y. Wei, S. Matar, L. Shen et al., "A novel membrane for DMFC$\mathrm{Na}_{2} \mathrm{Ti}_{3} \mathrm{O}_{7}$ Nanotubes/Nafion ${ }^{\circledR}$ composite membrane: performances studies," International Journal of Hydrogen Energy, vol. 37, no. 2, pp. 1857-1864, 2012.

[9] S. Matar and H. Liu, "Effect of cathode catalyst layer thickness on methanol cross-over in a DMFC," Electrochimica Acta, vol. 56, no. 1, pp. 600-606, 2010.

[10] K.-Y. Cho, J.-Y. Eom, H.-Y. Jung et al., "Characteristics of PVdF copolymer/Nafion blend membrane for direct methanol fuel cell (DMFC)," Electrochimica Acta, vol. 50, no. 2-3, pp. 583-588, 2004.

[11] H. Park, Y. Kim, Y. S. Choi, W. H. Hong, and D. Jung, "Surface chemistry and physical properties of Nafion/polypyrrole/Pt composite membrane prepared by chemical in situ polymerization for DMFC," Journal of Power Sources, vol. 178, no. 2, pp. 610-619, 2008.

[12] C.-C. Yang and Y.-J. Lee, "Preparation of the acidic PVA/MMT nanocomposite polymer membrane for the direct methanol fuel cell (DMFC)," Thin Solid Films, vol. 517, no. 17, pp. 4735-4740, 2009.

[13] C. H. Lee, W. Xie, D. VanHouten et al., "Hydrophilic silica additives for disulfonated poly(arylene ether sulfone) random copolymer membranes," Journal of Membrane Science, vol. 392393, pp. 157-166, 2012.

[14] J. Jaafar, A. F. Ismail, T. Matsuura, and K. Nagai, "Performance of SPEEK based polymer-nanoclay inorganic membrane for DMFC," Journal of Membrane Science, vol. 382, no. 1-2, pp. 202211, 2011.

[15] C. S. Karthikeyan, S. P. Nunes, L. A. S. A. Prado et al., "Polymer nanocomposite membranes for DMFC application," Journal of Membrane Science, vol. 254, no. 1-2, pp. 139-146, 2005.

[16] D. H. Jung, S. Y. Cho, D. H. Peck, D. R. Shin, and J. S. Kim, "Preparation and performance of a Nafion/montmorillonite nanocomposite membrane for direct methanol fuel cell," Journal of Power Sources, vol. 118, no. 1-2, pp. 205-211, 2003.

[17] S.-K. Kim, H.-D. Kwen, and S.-H. Choi, "Radiation-induced synthesis of vinyl copolymer based nanocomposites filled with reactive organic montmorillonite clay," Radiation Physics and Chemistry, vol. 81, no. 5, pp. 519-523, 2012.

[18] C. H. Manoratne, R. M. G. Rajapakse, and M. A. K. L. Dissanayake, "Ionic conductivity of poly(ethylene oxide)(PEO)montmorillopnite(MMT) nanocomposites prepared by intercalation form aqueous medium," International Journal of Elctrochemical Science, vol. 1, no. 1, pp. 32-46, 2006. 
[19] M. Qtaishat, D. Rana, M. Khayet, and T. Matsuura, "Preparation and characterization of novel hydrophobic/hydrophilic polyetherimide composite membranes for desalination by direct contact membrane distillation," Journal of Membrane Science, vol. 327, no. 1-2, pp. 264-273, 2009.

[20] Y. H. Cai, J. Hu, H. P. Ma, B. L. Yi, and H. M. Zhang, "Effects of hydrophilic/hydrophobic properties on the water behavior in the micro-channels of a proton exchange membrane fuel cell," Journal of Power Sources, vol. 161, no. 2, pp. 843-848, 2006. 

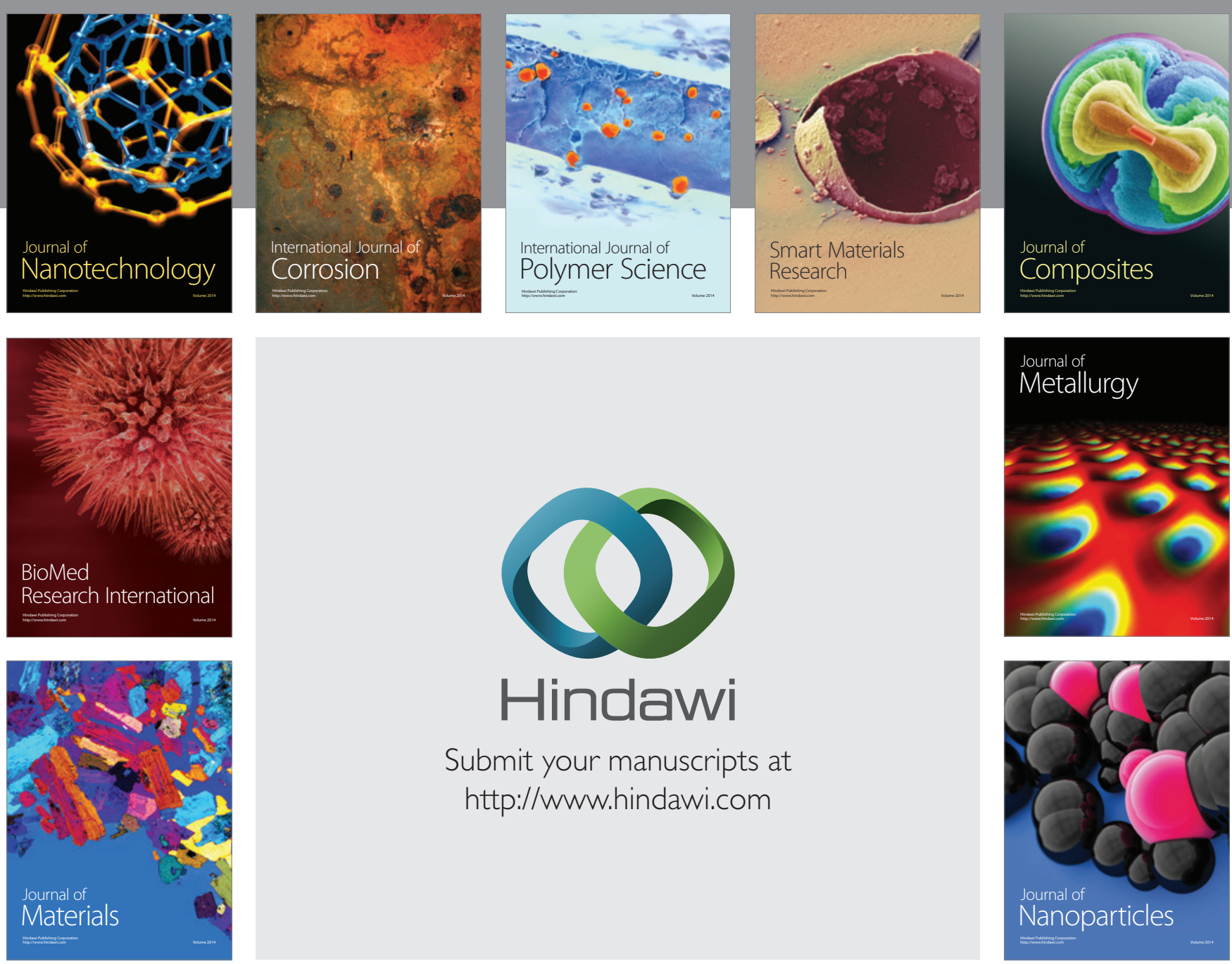

Submit your manuscripts at http://www.hindawi.com
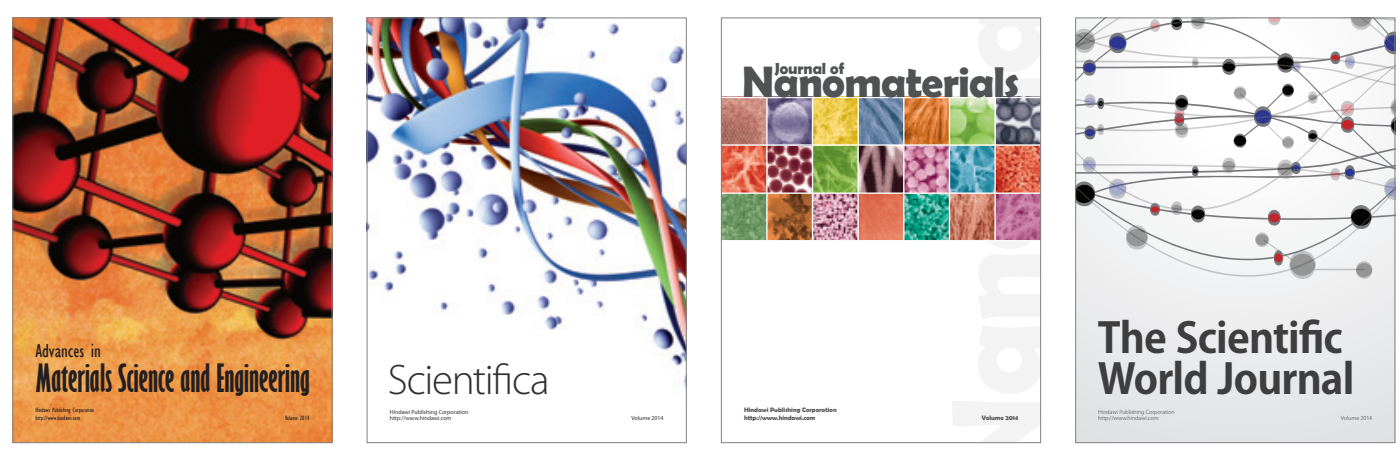

\section{The Scientific World Journal}
